\title{
Acute and chronic effects of cadmium on blood homeostasis of an estuarine crab, Chasmagnathus granulata, and the modifying effect of salinity
}

\section{E.M. Rodríguez ${ }^{1}$, R. Bigi ${ }^{1}$, D.A. Medesani, V.S. Stella ${ }^{1}$, L.S.L. Greco ${ }^{1}$, P.A.R. Moreno ${ }^{1}$, J.M. Monserrat', G.N. Pellerano ${ }^{1}$ and M. Ansaldo ${ }^{3}$}

\author{
${ }^{1}$ Departamento de Ciencias Biologicas, FCEyN, Pab. II, \\ Universidad de Buenos Aires, Buenos Aires, Argentina \\ ${ }^{2}$ Fundação Universidade do Rio Grande do Sul, \\ Rio Grande, RS, Brasil \\ 3 Instituto Antarctico Argentino, Buenos Aires, Argentina
}

\section{Correspondence \\ E.M. Rodríguez \\ Departamento de Ciencias Biologicas FCEyN, Pab. II \\ Universidad de Buenos Aires Ciudad Universitaria \\ 1428 Buenos Aires, Argentina Fax: + 54-11-4576-3384 \\ E-mail: enrique@ bg.fcen.uba.ar}

Research supported by Universidad de Buenos Aires (UBACYT 94-97 and UBACYT 98-2000).

Received August 3, 2000

Accepted January 3, 2001

\section{Abstract}

Whole body oxygen consumption and some hemolymph parameters such as $\mathrm{pH}$, partial pressure of gases, level of ions and lactate were measured in the estuarine crab Chasmagnathus granulata after both acute ( $96 \mathrm{~h}$ ) and chronic ( 2 weeks) exposure to cadmium at concentrations ranging from 0.4 to $6.3 \mathrm{mg} / \mathrm{l}$. In all instances, the crabs developed hemolymph acidosis, but no respiratory (increased $\mathrm{P}_{\mathrm{CO}_{2}}$ ) or lactate increases were evident. Hemolymph levels of sodium and calcium were always increased by cadmium exposure. The chronic toxicity of cadmium was enhanced at $12 \%$ salinity, even causing a significantly higher mortality in comparison with the higher salinity (30\%o) used. A general metabolic arrest took place at $12 \%$ salinity in the crabs chronically exposed to cadmium, as indicated by decreases of oxygen consumption and $\mathrm{P}_{\mathrm{CO}_{2}}$, an increase of $\mathrm{P}_{\mathrm{O}_{2}}$, along with no changes in lactate levels. These imbalances were associated with severe necrosis and telangiectasia in the respiratory gills, probably leading to respiratory impairment and finally histotoxic hypoxia and death of the animals.

\section{Introduction}

Chasmagnathus granulata is an estuarine crab living along the South American Atlantic coast from Rio de Janeiro (Brazil) to Puerto Deseado (Argentina) (1). Some estuarine environments, such as Lagoa dos Patos (Brazil), Samborombón Bay and Mar Chiquita (Argentina), are densely populated by this species. Both adults and juveniles live mainly in burrows in coastal muddy flats, being omnivorous detritivores (2) and serving as food for several fish species of high commercial value that reproduce in Samborombón Bay (3).

Samborombón Bay is located in the external, open sector of the Rio de la Plata estuary, where pollution is significantly lower than in other sectors (4). Nevertheless, cadmium was detected above permissible levels in $82 \%$ of 
water samples from the Rio de la Plata estuary, with mean values ranging from 2 to $4 \mu \mathrm{g} / \mathrm{l}$ (4). Furthermore, the cadmium concentration found in superficial sediments was $9.43 \pm 4.63 \mu \mathrm{g} / \mathrm{g}$, while a concentration of $11.91 \pm 6.39 \mu \mathrm{g} / \mathrm{g}$ was reported in suspended material from the more polluted areas (5).

The acute lethal toxicity of cadmium has been previously reported for $C$. granulata, as well as its inhibitory effect on carbonic anhydrase $(6,7)$. It has been widely reported for both vertebrate and invertebrate animals $(8,9)$ that heavy metals can bind to several proteins, including enzymes, altering their functions. Accordingly, several physiological processes, including those involved in blood homeostasis, have been considered in studies of sublethal effects of heavy metals on aquatic fauna $(8,10)$. These studies have examined gas exchange, ion regulation and acid-base balance, closely related processes that are finely regulated, especially in intertidal crabs (11-13).

Salinity is one of the most variable parameters in the estuarine environments where C. granulata lives. For example, in Samborombón Bay the salinity ranges from 12 to $18 \%$ near the mouth of the Salado River (14). Near Punta Rasa Cape (15), where the tidal influence is strong, the crabs are exposed to salinities of 20 to $30 \%$. As a consequence of the fluctuations of salinity, the crabs typically possess highly developed mechanisms for ion regulation. The estuarine crab $C$. granulata is a strong hyperregulatory species (16).

Several effects of salinity on heavy metal toxicity have been reported for crustaceans. As a rule, the toxicity of a heavy metal increases as the salinity decreases. This fact has been reported for several crustaceans both in studies of lethal $(6,17)$, and sublethal (18-21) effects.

This study was designed to identify under acute and chronic exposure to sublethal concentrations the imbalances caused by cadmium to blood homeostasis of C. granu- lata, mainly the effects on levels of gases, ions and organic metabolites, in order to determine the nature and significance of the produced changes. In addition, the influence of environmental salinity as a factor modifying cadmium toxicity was assessed.

\section{Material and Methods}

Adult $C$. granulata crabs were used in all experiments. In order to minimize biological variations in response, only males were studied. The animals were collected on Faro San Antonio beach, at the southern end of Samborombón Bay ( $\left.36^{\circ} 18^{\prime} \mathrm{S}, 56^{\circ} 48^{\prime} \mathrm{W}\right)$. The concentrations of heavy metals in crabs sampled at this site have been reported to be below the detection limits of atomic absorption spectrophotometry (7). Once in the laboratory, crabs were maintained for two weeks under the same environmental conditions that would be used later in the bioassays: 12-h light/12-h dark photoperiod (fluorescent light), temperature of $20 \pm 1^{\circ} \mathrm{C}, \mathrm{pH} 7.4$ \pm 0.1 , dissolved oxygen at $>90 \%$ of saturation, and 12 or $30 \%$ salinity. The saline water was prepared from dechlorinated tap water (total hardness: $80 \mathrm{mg} / \mathrm{l}$ as $\mathrm{CaCO}_{3}$ equivalents) and Marine Mix (Wiegandt, Krefeld, Germany) salts for artificial marine water. On the basis of the results obtained in a previous study of $C$. granulata (16), crabs were acclimated for two weeks to the above salinities. During this acclimation period, the crabs were fed twice a week with commercially available pellets of rabbit food and chicken liver, as in previous studies $(6,7)$.

After the acclimation period, 10 crabs were randomly assigned to each 24-liter capacity glass aquarium, which contained 3 liters of test solution, enough for the crabs to be submerged. The toxicological bioassays followed the guidelines of the American Public Health Association (22). In all cases, a cadmium stock solution $(10 \mathrm{~g} / \mathrm{l})$ was prepared from hemipentahydrated cadmium chloride (Baker, Ltd., Phillipsburg, NJ, USA) 
and distilled water. In addition, a control group was always run, containing only 10 crabs and the artificial saline water used in all test solutions. The following experiments were conducted in order to test for the acute and chronic effects of cadmium under the influence of different salinities.

\section{Acute effects}

Crabs for this set of experiments were collected on July 1995. The mean wet weight $( \pm$ SEM) of the crabs used was $13.85 \pm 2.07$ $\mathrm{g}(\mathrm{N}=80)$. These assays were conducted only at $12 \%$ salinity. Two series, each comprising a control and cadmium concentrations of $0.4,1.6$ and $6.3 \mathrm{mg} / \mathrm{l}$, were run. For each series, independent aquaria with 10 crabs each were used for each cadmium concentration and control. The concentrations were below the 96-h LC50 value (25.1 $\mathrm{mg} / \mathrm{l})$ previously determined for the same species with this toxicant and salinity (19). The crabs were exposed for $96 \mathrm{~h}$ without feeding. At the end of the exposure period, crabs from all treatments were subjected to the following sequential procedure:

Gas analysis. A hemolymph sample (80 $\mu 1)$ was taken from crabs of the first series with a capillary tube, from the base of a fourth or fifth pereiopod, in order to analyze $\mathrm{pH}$ and the partial pressures of $\mathrm{CO}_{2}\left(\mathrm{P}_{\mathrm{CO}_{2}}\right)$ and $\mathrm{O}_{2}\left(\mathrm{P}_{\mathrm{O}_{2}}\right)$, by means of a Radiometer BMS3 Mk2 Blood microsystem, thermostated at $20^{\circ} \mathrm{C}$.

Ion and carbohydrate analysis. A second hemolymph sample of $0.5 \mathrm{ml}$ was taken immediately after the first one with a 1-ml syringe provided with a $27-\mathrm{G}$ needle, from the same site, and immediately transferred to a 1-ml Eppendorf tube for storage at $-20^{\circ} \mathrm{C}$ until analysis. Sodium and potassium concentrations were determined by flame photometry (Crudo Caamaño SRL, Buenos Aires, Argentina). Colorimetric methods were used to measure free calcium (Boehringer kit, Mannheim, Germany), chloride (Wienner kit,
Rosario, Argentina) and L-lactate (BioMérieux kit, enzymatic method, Lyon, France).

Oxygen consumption. Crabs of the second series were placed for $60 \mathrm{~min}$ in constant-pressure respirometers (23) and their aerial respiratory rate was measured. Oxygen volume was standardized to $760 \mathrm{mmHg}$ and $273^{\circ} \mathrm{K}$. Respiratory rate was expressed as $\mu 1 \mathrm{O}_{2} \mathrm{~min}^{-1} \mathrm{~g}^{-1}$ of fresh body weight.

Gill dissection. After determining oxygen consumption, the right third (respiratory) and eighth (osmoregulatory) gills of each crab were dissected and fixed in Bouin solution for $12 \mathrm{~h}$, dehydrated in a progressive alcohol series, embedded in Paraplast, cut into $6-\mu \mathrm{m}$ sections, and stained with hematoxylin-eosin and Masson trichrome.

\section{Chronic effects - influence of salinity}

Crabs for this set of experiments were collected on March 1996. The mean wet weight $( \pm$ SEM) of the crabs used was $12.60 \pm 2.41 \mathrm{~g}$ $(\mathrm{N}=80)$. A cadmium concentration of $5 \mathrm{mg} / \mathrm{l}$ was used, in parallel with a clean water control, at two different salinities, 12 and 30\%o, in two series. Each series comprised 10 crabs for each combination of salinity and treatment (control or cadmium). The crabs were exposed for two weeks; during this period they were fed as mentioned for the acclimation period, and all test solutions were renewed $6 \mathrm{~h}$ after food was provided.

At the end of the exposure period, a sample of hemolymph was taken from each animal of one series to determine $\mathrm{pH}, \mathrm{P}_{\mathrm{CO}_{2}}$, $\mathrm{P}_{\mathrm{O}_{2}}$ and concentrations of $\mathrm{Na}^{+}, \mathrm{K}^{+}, \mathrm{Ca}^{2+}, \mathrm{Cl}^{-}$ and lactate, while the crabs of the second series were used for oxygen consumption determination and gill dissection. In all cases, the same methodology as described for the acute assay was followed.

\section{Statistical analysis}

Data for each of the variables considered 
in the acute toxicity assay were analyzed by one-way ANOVA (factor $\mathrm{Cd} 3$ ), while twoway ANOVA was used to analyze data from the chronic toxicity assay, taking as factors cadmium concentration and salinity. In all cases, a priori planned comparisons (24) were made to compare each cadmium concentration versus control. Logarithmic transformation of data was made when homogeneity of variances was not eventually confirmed for raw data.

Figure 1 - Mean values ( \pm SEM) of hemolymph parameters and physiological variables for Chasmagnathus granulata exposed to various concentrations of cadmium (mg/l) for $96 \mathrm{~h}$ at $12 \%$ osalinity. Control: Water dilution control. $\mathrm{N}=10$ in all cases. $* \mathrm{P}<0.05$ compared to control (one-way ANOVA followed by planned comparisons test).
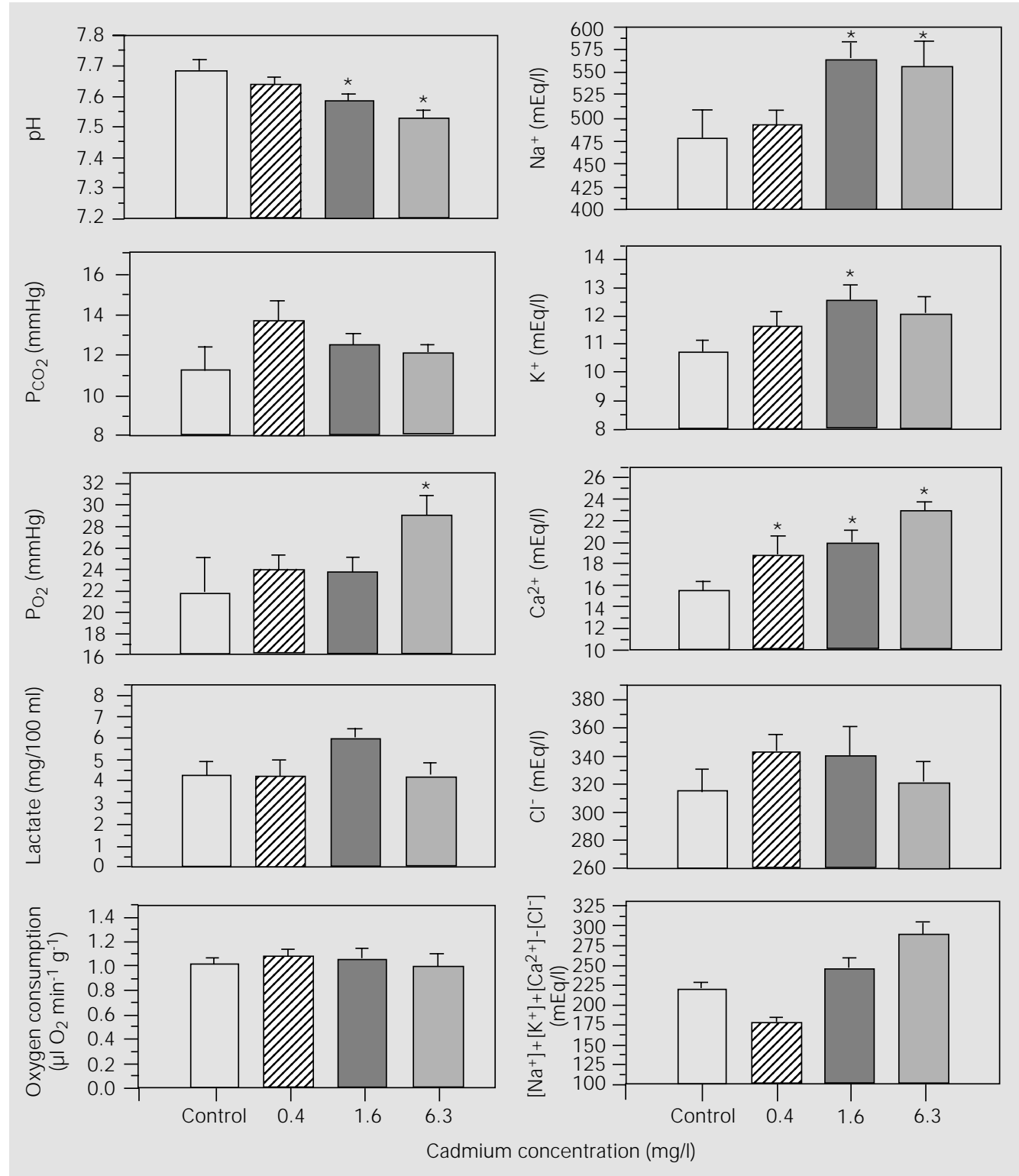
tions $(1.6$ and $6.3 \mathrm{mg} / \mathrm{l})$. No significant differences were detected for $\mathrm{P}_{\mathrm{CO}_{2}}$, lactate, oxygen consumption or chloride. Partial oxygen pressure was significantly higher $(\mathrm{P}<0.05)$ than the control value at $6.3 \mathrm{mg} / \mathrm{l}$ cadmium, while potassium was significantly $(\mathrm{P}<0.05)$ increased, but only at $1.6 \mathrm{mg} / \mathrm{l}$ cadmium. Sodium significantly $(\mathrm{P}<0.05)$ rose at 1.6 and $6.3 \mathrm{mg} / \mathrm{l}$ while calcium increased at all the concentrations assayed. No significant differences were detected between any cadmium concentration and control in strong ion difference (SID), estimated from the difference between the measured strong cations and anions.

The main pathologies detected in the gills were hyperplasia and telangiectasia, although at a low extent in both cases. Hyperplasia was mainly observed in lamellae, and in marginal channels to a lesser extent (Figure 2B). Conversely, a discrete telangiectasia (accumulation of hemolymph) was observed in marginal channels rather than in the lamellae. Hyperplasia was observed mainly in the third gill, while telangiectasia was more com-
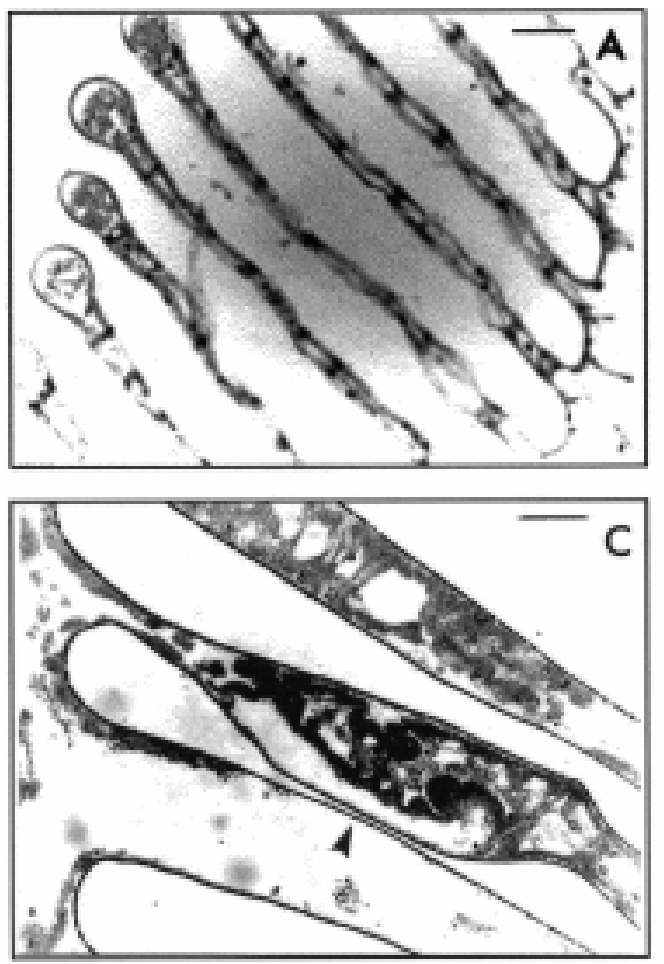

monly seen in the eighth gill.

\section{Chronic effects - influence of salinity}

Mortality (40\%) only occurred in cadmium-exposed crabs maintained at $12 \%$. Figure 3 summarizes the results obtained for the hemolymph parameters after the 2-week exposure period, as well as the result of the statistical comparisons made between the mean values of the exposed and control crabs for each of the assayed salinities. Some significant differences caused by cadmium $(\mathrm{P}<0.001)$ were found both at 12 and $30 \%$, i.e., a decrease of $\mathrm{pH}$ and an increase in $\mathrm{P}_{\mathrm{O}_{2}}$ and $\mathrm{Ca}^{2+}$ levels. However, some other significant differences $(\mathrm{P}<0.05)$ between the cadmium-exposed and control crabs were only found at $12 \%$ salinity; these were a decrease of $\mathrm{P}_{\mathrm{CO}_{2}}$ and oxygen consumption, as well as an increase of $\mathrm{Na}^{+}$levels and measured SID. A drop in $\mathrm{K}^{+}$concentration was noted at $30 \%$ in cadmium-exposed crabs. Significant effects $(\mathrm{P}<0.05)$ of salinity as a factor were only noted for potassium and
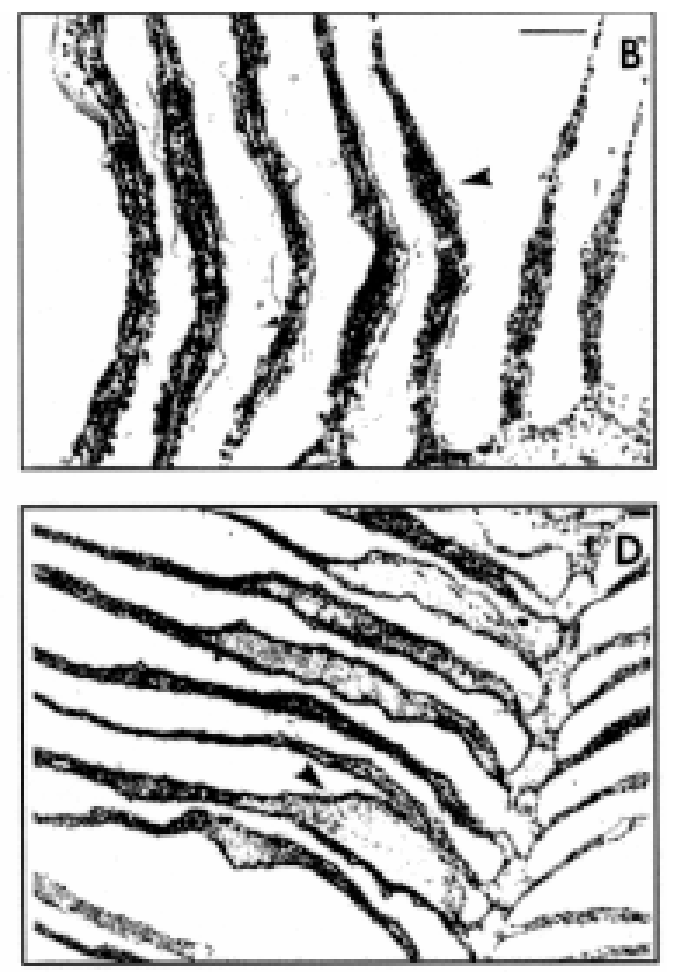

Figure 2 - Pathologies of the respiratory gills observed in both acute and chronic assays at $12 \%$ salinity. A, Normal architecture (control); B, hyperplasia (6.3 $\mathrm{mg} / \mathrm{l}$ cadmium, acute assays); $\mathrm{C}$, necrosis $(5 \mathrm{mg} / \mathrm{l}$ cadmium, chronic assay); $\mathrm{D}$, telangiectasia (5 mg/l cadmium, chronic assay). All mentioned pathologies are indicated with arrowheads. Horizontal bars: $10 \mu \mathrm{m}$. 
Figure 3 - Mean values ( \pm SEM) of hemolymph parameters and physiological variables for Chasmagnathus granulata exposed to cadmium for 2 weeks at 12 and $30 \%$ (ppt) salinity. Control: Water dilution control. $\mathrm{N}=10$, except for $5 \mathrm{mg} / \mathrm{l}$ cadmium at $12 \%$ o salinity $(\mathrm{N}=6)$. $* \mathrm{P}<0.05 \mathrm{com}-$ pared to control (two-way ANOVA followed by planned comparisons test).
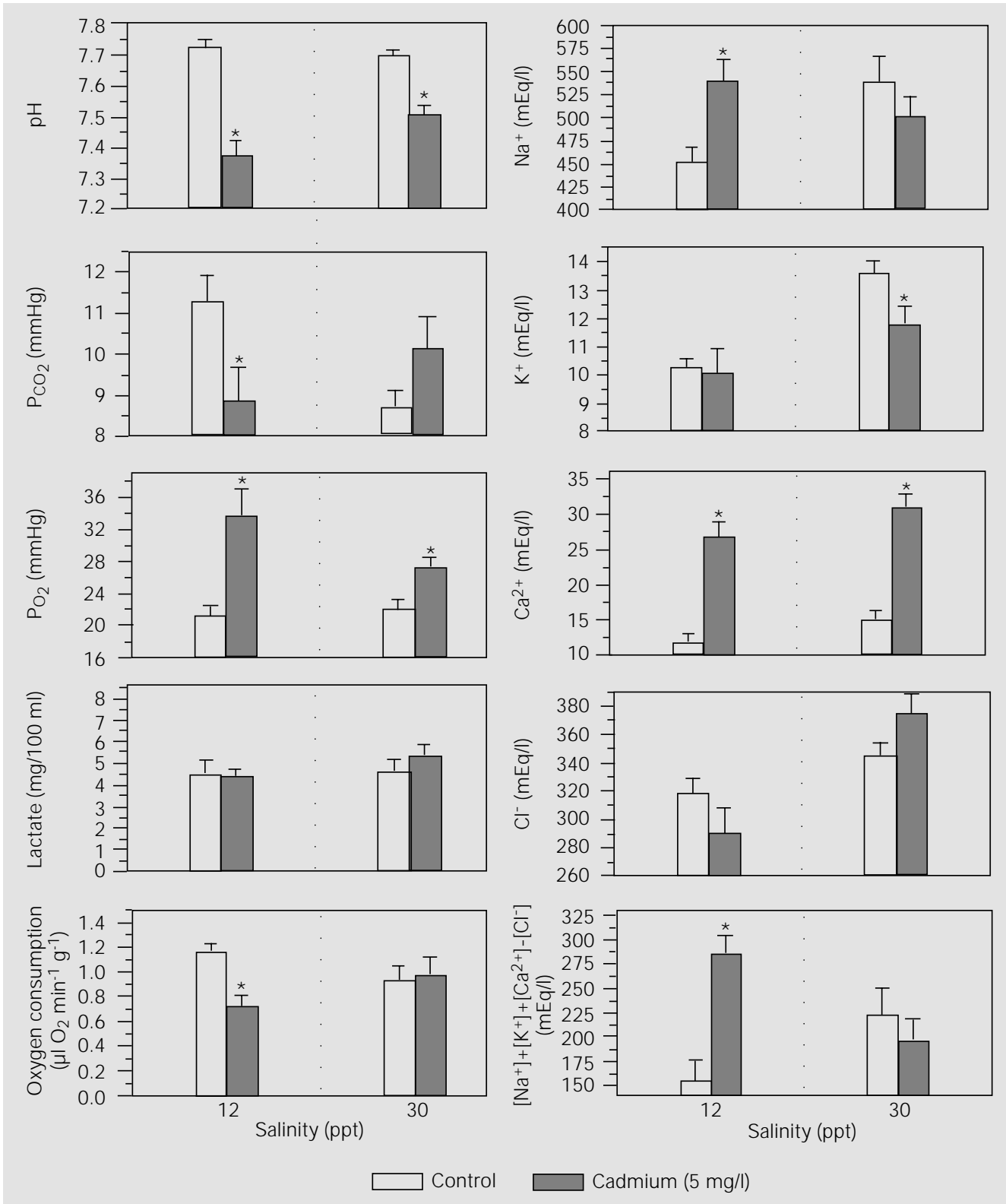

chloride levels, which were higher at 30 than at $12 \%$ o $(\mathrm{P}<0.05)$.

Histopathological analysis showed incipient to moderate necrosis in osmoregulatory gills, consisting of vacuolization and edematization of lamellar epithelium leading to swelling of inocytes. Severe necrosis, with rupture of epithelial and pillar cells, was often seen in respiratory gills (Figure 2C). Moderate to severe telangiectasia was also seen in these gills (Figure 2D), i.e., partial or massive infiltration of lamellae with hemolymph, with lack of the normal circulatory compartmentalization. The strongest effects of cadmium were seen at the lowest salinity assayed.

\section{Discussion}

From an ecotoxicological point of view, the concentrations used in this study that caused significant effects on the measured 
parameters $(1.6$ and $6.3 \mathrm{mg} / \mathrm{l}$ in the acute assay and $5 \mathrm{mg} / \mathrm{l}$ in the chronic one) can potentially be found by crabs in their natural environment. As stated in the Introduction, the cadmium concentration reported in sediments and suspended material from the Rio de la Plata estuary averages $10 \mu \mathrm{g} / \mathrm{g}$ (i.e., 10 parts per million) in the more polluted areas. Although C. granulata lives in Samborombón Bay, an area thus far relatively free of pollution, the potential risk of cadmium for this species should be seriously considered, especially taking into account that $C$. granulata is a detritivore, sediment-consumer species (2). Cadmium, like other heavy metals, presents a high absorption to fine sediments such as clay, abundant in the bottom and coastal areas of the mentioned estuary (4).

According to Bjerregaard and Vislie (25), total levels of cadmium in the hemolymph of the crab Carcinus maenas are slightly below ambient cadmium concentrations $\leq 2 \mathrm{mg} / \mathrm{l}$, but hemolymph cadmium concentration increases up to 3-fold with respect to ambient cadmium concentrations ranging from 4 to $10 \mathrm{mg} / \mathrm{l}$. Since these ambient concentrations and most of the experimental conditions used in that study were similar to those used in the present one, in principle we can consider these results to be representative for $C$. granulata. It is also known that competition occurs between calcium and cadmium for intake through crustacean gills, using the calcium uptake routes (26). It has been reported that cadmium uptake increases in amphipods as ambient calcium concentrations decrease (27), although a higher intake of cadmium with decreasing salinity is not a general rule for all crustaceans (26).

A marked acidosis developed after cadmium exposure both in the acute and chronic assays. Neither a respiratory component (indicated by increasing $\mathrm{P}_{\mathrm{CO}_{2}}$ ) nor a metabolic one (i.e., an increase in hemolymph lactate concentration) was evident in the two assays. A possible role of cadmium binding to plasma proteins should be considered in or- der to explain the plasma acidosis caused by cadmium. This metal has the capacity to bind to hemocyanin molecules $(28,29)$. Hemocyanins represent $95 \%$ of the plasma proteins in crustaceans (30). Cadmium is able to alter polymerization of the hemocyanin molecule by binding to allosteric sites (28), thereby affecting the free ionic force and possibly also the hemocyanin buffering capacity. Since $\mathrm{P}_{\mathrm{O}_{2}}$ increased in crabs both acutely and chronically exposed to cadmium, a possible reduction in the affinity of the hemocyanin molecule for oxygen may also have occurred. Although the decrease in oxygen consumption observed in the chronic assay may also have been responsible for the increased $\mathrm{P}_{\mathrm{O}_{2}}$, this was not the case for the acute assay, a result supporting the hypothesis of a possible reduction of hemocyanin oxygen affinity by the effect of cadmium.

A significant effect of cadmium on sodium and calcium concentrations was evident both in the acute and chronic assays. A marked increase in the plasma concentration of both sodium and calcium was also reported in experiments with the crab Carcinus maenas exposed to cadmium (25). In Carcinus maenas exposed to copper, a nonlactic metabolic acidosis was reported, associated with a decrease of sodium and other ion levels, becoming more severe with decreasing salinity (19). The increase of sodium levels in $C$. granulata could be related to an attempt to return to normal $\mathrm{pH}$ through an increase in SID, with higher SID values corresponding to higher $\mathrm{pH}$ values $(10,24$, for crabs). Since wide variation in SID values was observed among treatments, without a clear correlation with $\mathrm{pH}$ changes, no major physiological role of SID was observed for $\mathrm{pH}$ homeostasis.

Nevertheless, it should be noted that no inhibition of gill $\mathrm{Na}^{+} / \mathrm{K}^{+}$-ATPase was found in a previous in vivo study with C. granulata acutely exposed to the range of cadmium concentrations used in the experiments described here (31). Furthermore, this lack of 
inhibition was also seen under conditions of chronic exposure(Moreno PAR, Schwarzbaum $\mathrm{P}$ and Rodríguez EM, unpublished results). Therefore, the primary active mechanism for sodium uptake (i.e., $\mathrm{Na}^{+} / \mathrm{K}^{+}$-ATPase) seems to function normally in cadmium-exposed crabs. However, we cannot rule out a possible effect of cadmium on apical transporters and channels for sodium; in this respect, it has been reported that cadmium stimulates sodium absorption across the amphibian skin at the level of the apical membrane (32).

Concerning the calcium increase (Figures 1 and 3), dissolution of calcium carbonate from the exoskeleton for hemolymph buffering has been described for crabs during air breathing (12) and under other environmental conditions (30) as a consequence of plasma acidosis. This homeostatic response should not be ignored in C. granulata exposed to cadmium. However, the observed increase in plasma calcium could be related to a competitive displacement at the calcium pump level or to blockage of calcium channels by cadmium (9), preventing normal calcium uptake in most tissues and therefore increasing the hemolymph calcium levels. The possible displacement of calcium by cadmium from binding sites in plasma proteins, therefore increasing hemolymph free calcium levels, should also be considered.

By comparing the results from the experiments with the two salinities run in the 2week assay (Figure 3), it is clear that the toxicity of cadmium was enhanced at the lower salinity, as reported for several other crustaceans (9,18-20) and even for C. granulata concerning carbonic anhydrase activity (6). Control crabs maintained for 2 weeks at $12 \%$ salinity showed values similar to those of control crabs maintained at the same salinity in the acute assay. The higher levels of potassium and chloride observed at $30 \%$ compared to those observed at $12 \%$ o (effect of salinity by itself) were possibly related to the less developed regulation of these ions compared to others such as sodium (16).
The higher toxicity caused by cadmium at $12 \%$ o than at $30 \%$ was mainly caused by the general metabolic arrest that took place at the lower salinity. Several concomitant changes are indicative of such metabolic arrest, such as decreased oxygen consumption, decreased $\mathrm{P}_{\mathrm{CO}_{2}}$ and increased $\mathrm{P}_{\mathrm{O}_{2}}$, together with no change in lactate level. However, we cannot rule out that a transient hypoxemia and lactacidemia could occur before that, not detected at the time we sampled hemolymph. The observed metabolic drop could be due to histotoxic hypoxia related to tissue necrosis, or to blockade of the main metabolic pathways in several tissues (33).

The latter results show a correlation with the observations made on gills. While in the acute assay all pathologies detected occurred at a low extent, with no obvious correlation with hemolymph gas levels, in the chronic assay a moderate to severe necrosis and telangiectasia in the respiratory gills seem to be in accordance with the decrease in oxygen consumption and the possible histotoxic hypoxia mentioned above. Experiments made with copper on the crab Carcinus maenas showed gill hyperplasia, vacuolization and necrosis both at sublethal and lethal levels (34). These pathologies seemed to cause respiratory impairment, leading to hypoxemia, lactacidemia, hemolymph acidosis and death. A recent study on $C$. granulata exposed to ammonia showed collapsing of gill lamellae, together with hypoxemia and lactacidemia, but no hemolymph acidosis (35).

Only an extreme imbalance in the blood acid-base status was reported to be lethal for fishes (36). As suggested for crabs exposed to copper (37), the hemolymph acidosis observed in $C$. granulata did not prove to be the cause of death in cadmium-exposed crabs. It was detected in both acute and chronic assays, but lethal effects were only seen in those animals exposed for 2 weeks to the lowest salinity, these crabs showing gill pa- 
thologies that seemed to cause respiratory impairment, finally leading to death of the animals. However, the hemolymph acidosis should not be excluded as a factor contributing to the observed mortality.

As main conclusions, we can state that the hemolymph acidosis developed both after an acute and a chronic exposure to cadmium was not related to a respiratory (increased $\mathrm{P}_{\mathrm{CO}_{2}}$ ) or to a metabolic (increased lactate) component. Moreover, its relevance for crab mortality was not evident. Rather, the present results suggest that the lethal effects of cadmium on $C$. granulata observed at $12 \%$ salinity at the end of the 2week exposure period are strongly associated with tissue histotoxic hypoxia caused by cadmium in most tissues.

\section{Acknowledgments}

We wish to thank Dr. Milton Fingerman (Tulane University, New Orleans, LA, USA) for a critical reading of the manuscript.

\section{References}

1. Boschi EE (1964). Los crustáceos decápodos brachyura del litoral bonaerense. Boletín del Instituto de Biología Marina Mar del Plata, 164: 1-34.

2. D'Incao $F$, da Silva $K G$, Rufino $M L \&$ da Costa Braga A (1990). Hábito alimentar do caranguejo Chasmagnathus granulata Dana, 1851 na barra do Rio Grande, RS (Decapoda, Grapsidae). Atlantica, 12: 8593.

3. Menni R (1983). Los Peces en el Medio Marino. Estudio Sigma, Buenos Aires.

4. Comisión Administradora del Río de La Plata (1990). Estudio para la evaluación de la contaminación en el Río de La Plata. Informe de Avance, Argentine Hydrographic Navy Service. Buenos Aires, Argentina.

5. Marcovecchio J E (1988). Estudio comparativo de la distribución de los metales traza mercurio, cadmio y zinc en organismos de dos zonas estuariales de Argentina: Bahía Blanca y desembocadura del Río de la Plata. Doctoral thesis, Universidad de Mar del Plata, Argentina.

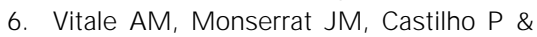
Rodríguez EM (1999). Inhibitory effects of cadmium on carbonic anhydrase activity and ionic regulation of the estuarine crab Chasmagnathus granulata (Decapoda, Grapsidae). Comparative Biochemistry and Physiology, 122C: 121-129.

7. Bigi R, Verrengia-Guerrero N, Rodríguez EM, Kesten E \& Medesani DA (1996). Acute lethal toxicity and bioaccumulation of cadmium in the estuarine crab Chasmagnathus granulata (Decapoda, Brachyura). In: Marcovecchio J (Editor), Pollution Processes in Coastal Environments. Mar del Plata, Argentina, 292-295.
8. Rand GM (1995). Fundamentals of Aquatic Toxicology. Effects, Environmental Fate, and Risk Assessment. 2nd edn. Taylor and Francis, Bristol, UK.

9. Rainbow PS \& Dallinger R (1993). Metal uptake, regulation and excretion in freshwater invertebrates. In: Dallinger $\mathrm{R} \&$ \& Rainbow PS (Editors), Ecotoxicology of Metals in Invertebrates. Lewis Publishers, Boca Raton, 119-131.

10. Giesy J P \& Graney RL (1989). Recent developments in and intercomparisons of acute and chronic bioassays and bioindicators. Hydrobiologia, 188-189: 21-60.

11. Böttcher K \& Siebers D (1993). Biochemistry, localization and physiology of carbonic anhydrase in the gills of euryhaline crabs. J ournal of Experimental Zoology, 265: 397-409.

12. Burnett LE (1988). Physiological responses to air exposure: acid-base balance and the role of branchial water stores. American Zoologist, 28: 125-135.

13. Henry RP \& Cameron J N (1983). The role of carbonic anhydrase in respiration, ion regulation and acid-base balance in the aquatic crab Callinectes sapidus and the terrestrial crab Gecarcinus lateralis. J ournal of Experimental Biology, 103: 205-223.

14. Botto J L \& Yrigoyen HR (1979). Biología de la comunidad del cangrejal. I. Contribución al conocimiento biológico del cangrejo estuarino Chasmagnathus granulata Dana (Crustacea, Decapoda, Grapsidae) en la desembocadura del Río Salado, provincia de Buenos Aires. In: UNESCO (Editor), Memorias del Seminario sobre Ecología Bentónica y Sedimentos de la Plataforma Continental del Atlántico Sur. Montevideo, Uruguay, 161-169.
15. Rossi J B (1982). Aspectos hidrobiológicos del Arroyo San Clemente (Bahía Samborombón). Revista del Museo de la Plata, 132: 29-38.

16. Bromberg $E$, Santos EA \& Bianchini A (1995). Osmotic and ionic regulation in Chasmagnathus granulata Dana, 1851 (Decapoda, Grapsidae) during hyposmotic stress. Nauplius, 3: 83-99.

17. O'HaraJ (1973). The influence of temperature and salinity on the toxicity of cadmium to the fiddler crab Uca pugilator. Fisheries Bulletin, 71: 149-153.

18. Zaunders IP \& Rojas WE (1996). Salinity effects on cadmium accumulation in various tissues of the tropical fiddler crab Uca rapax. Environmental Pollution, 94: 293299.

19. Boitel F \& Truchot J P (1989). Effects of sublethal and lethal copper levels on hemolymph acid-base balance and ion concentrations in the shore crab Carcinus maenas kept in undiluted sea water. Marine Biology, 103: 495-501.

20. Tedengren $M$, Arnér $M \&$ Kautsky $N$ (1988). Ecophysiological and stress response of marine and brackish water Gammarus species (Crustacea, Amphipoda) to changes in salinity and exposure to cadmium and diesel-oil. Marine Ecology, Progress Series, 47: 107-116.

21. Thurberg FP, Dawson MA \& Collier RS (1973). Effects of copper and cadmium on osmoregulation and oxygen consumption in two species of estuarine crabs. Marine Biology, 23: 171-175.

22. American Public Health Association, American Water Works Association \& Water Environmental Federation (1995). Standard Methods for the Examination of 
Water and Wastewater. 19th edn. American Public Health Association, Washington, DC.

23. Monserrat JM, Rodriguez EM \& Lombardo RJ (1991). Effects of salinity on the toxicity of parathion to the estuarine crab Chasmagnathus granulata (Decapoda, Grapsidae). Bulletin of Environmental Contamination and Toxicology, 46: 569-575.

24. Montgomery DC (1984). Design and Analysis of Experiments. 2nd edn. J ohn Wiley $\&$ Sons, New York.

25. Bjerregaard P \& Vislie T (1985). Effects of cadmium on hemolymph composition in the shore crab Carcinus maenas. Marine Ecology, 27: 135-142.

26. Rainbow PS (1997). Ecophysiology of trace metal uptake in crustaceans. Estuarine Coastal and Shelf Science, 44: 169175.

27. Stephenson M \& Mackie GL (1989). A laboratory study of the effects of waterborne cadmium, calcium, and carbonate concentrations on cadmium concentrations in Hyalella azteca (Crustacea: Amphipoda). Aquatic Toxicology, 15: 53-62.
28. Bubacco L, Rocco GP, Salvato B \& Beltamini M (1993). The binding of Cd (II) to the hemocyanin of the Mediterranean crab Carcinus maenas. Archives of Biochemistry and Biophysics, 302: 78-84.

29. Martin DJ \& Rainbow PS (1998). Haemocyanin and the binding of cadmium and zinc in the haemolymph of the shore crab Carcinus maenas (L.). Science of the Total Environment, 214: 133-152.

30. Mangum CP (1986). Osmoregulation in marine and estuarine animals, its influence on respiratory gas exchange and transport. Bulletin of Zoology, 53: 1-7.

31. Rodríguez Moreno PA, Schwarzbaum P \& Rodríguez EM (1998). Effects of cadmium on gill $\mathrm{Na}$, K-ATPase of the estuarine crab Chasmagnathus granulata during postmolt: in vivo and in vitro studies. Bulletin of Environmental Contamination and Toxicology, 61: 629-636.

32. Hillyard SD, Sera R \& Gonick HC (1979). Effect of $\mathrm{Cd}^{++}$on short-circuit current across epithelial membranes. J ournal of Membrane Biology, 46: 283-294.

33. Silverthom DU (1998). Human Physiology. An Integrated Approach. Prentice Hall,
New J ersey.

34. Nonnotte L, Boitel F \& Truchot J P (1993). Waterborne copper causes gill damage and hemolymph hypoxia in the shore crab Carcinus maenas. Canadian J ournal of Zoology, 71: 1569-1576.

35. Freitas Rebelo M, Rodríguez EM, Santos EA \& Ansaldo M (2000). Histopathological changes in gills of the estuarine crab Chasmagnathus granulata (Crustacea-Decapoda) following acute exposure to ammonia. Comparative Biochemistry and Physiology, 125C: 157-164.

36. Cameron J N (1989). Acid-base regulation in fishes. 2. Biological responses and limitations. In: Morris R, Taylor EW, Brown DJ A \& Brown J A (Editors), Acid Toxicity and Aquatic Animals. Cambridge University Press, Cambridge, UK, 99-112.

37. Boitel F \& Truchot J P (1990). Comparative study of the effects of copper on haemolymph ion concentrations and acid-base balance in shore crabs Carcinus maenas acclimated to full-strength or dilute seawater. Comparative Biochemistry and Physiology, 95C: 307-312. 